\title{
Cikkismertetés: Hogyan változott a dohányzás és betegségterhe 1990 és 2019 között?
}

Article review: How has the burden of smoking and disease changed between 1990 and 2019?

Ismertető:

Ismertetett cikk:

\section{Vitrai József}

GBD 2019 Tobacco Collaborators (2021). Spatial, temporal, and demographic patterns in prevalence of smoking tobacco use and attributable disease burden in 204 countries and territories, 1990-2019: a systematic analysis from the Global Burden of Disease Study 2019. Lancet (London, England), S0140-6736(21)01169-7. Advance online publication. doi: 10.1016/S0140-6736(21)01169-7

Kulcsszavak: dohányzás; halálozás; betegségteher; elvesztett egészséges életévek Keywords: $\quad$ smoking; mortaliy; disease burden; disability-adjusted life-years

\section{HÁTTÉR}

A világszerte jelentkező dohányzási járvány felszámolása a globális egészségügy egyik meghatározó kihívása. A dohányzás visszaszorítására irányuló nemzeti és nemzetközi erőfeszítések irányításához időben és átfogó becslésekre van szükség a dohányhasználat elterjedtségére és a dohányzásnak tulajdonítható betegségterhekre vonatkozóan.

\section{MÓDSZEREK}

A szerzők a Global Burden of Diseases, Injuries, and Risk Factors Study keretében 1990 és 2019 között 204 országra és területre vonatkozóan becsülték meg a füstképzéssel járó dohányzás prevalenciáját és a dohányzásnak tulajdonítható betegségterhet kor és nem szerint. Több, dohányzással kapcsolatos mutatót modelleztek 3625 országos reprezentatív felmérés adatai alapján. Elvégezték a szakirodalom szisztematikus áttekintését és Bayes-féle metaregressziós eljárásokkal 36 ok-okozati összefüggésben álló egészségügyi kimenetelre vonatkozóan megbecsülték a jelenlegi és korábbi dohányosok nemlineáris dózis-válasz kockázati görbéit.
Közvetlen becslési megközelítést alkalmaztak a dohányzásnak tulajdonítható terhek becslésére, így a dohányzás egészségre gyakorolt hatásaira a korábbiaknál átfogóbb becslést tudtak adni.

\section{EREDMÉNYEK}

2019-ben globálisan 1,14 milliárd (95\%-os megbízhatósági intervallum 1,13-1,16) személy volt a felméréskor dohányos, akik 7,41 billió $(7,11-7,74)$ cigaretta-egyenértéknyi dohányt fogyasztottak. Bár a dohányzás előfordulása 1990 óta jelentősen csökkent mind a 15 éves és idősebb férfiak (27,5\%-os [26,5-28,5] csökkenés), mind a nők (37,7\%-os [35,4-39,9] csökkenés) körében, a népességnövekedés következtében a dohányosok összlétszáma jelentősen megnőtt az 1990-es 0,99 milliárdról (0,98-1,00). Magyarországon a dohányzás gyakorisága nőknél 18,4\%kal (6,32\%-29,4\%) csökkent 1990 és 2019 között, míg férfiaknál a csökkenés mértéke 21,7\% $(15,6 \%-27,2 \%)$ volt.

Világszerte 2019-ben a dohányzás 7,69 millió $(7,16-8,20)$ halálesetet okozott és 200 millió (185-214) elvesztett egészséges életévért volt felelős, és a férfiak körében a halálozás vezető kockázati tényezője volt (a férfiak halálozásának 
20,2\%-a [19,3-21,1]). ${ }^{1}$ A dohányzás okozta 7,69 millió halálesetből 6,68 millió [86,9\%] az aktív dohányosok körében következett be.

\section{MEGBESZÉLÉS}

Beavatkozás hiányában a dohányzásnak tulajdonítható évi 7,69 millió haláleset és 200 millió elvesztett egészséges életév száma a következő évtizedekben növekedni fog. A dohányzás gyakoriságának csökkentése terén jelentős előrelépés figyelhető meg valamennyi régióban és a fejlődés minden szakaszában lévő országban, de a dohányzás visszaszorítása terén még mindig nagy különbségek tapasztalhatók. Az országok világos és sürgető feladata erős, bizonyítékokon alapuló szakpolitikák elfogadása annak érdekében, hogy felgyorsítsák a dohányzás elterjedtségének csökkentését, és polgáraik számára jelentős egészségi előnyöket biztosítsanak.

\section{TANULSÁGOK A HAZAI SZAKEMBEREK SZÁMÁRA}

Szakértői becslések igazolják, a dohányzás még ma is komoly terhet jelent a magyar társadalom számára. A dohányzás visszaszoritására hozott hazai jogszabályok és a néhány éve elindított leszokástámogatási programok, úgy látszik, nem kielégítőek: a 2019-ben elvégzett Európai Lakossági Egészségfelmérés adatai szerint 2014 óta nem csökkent a naponta dohányzók aránya Magyarországon. Nemzetközi tapasztalatok igazolják a levonható következtetést: csakis az elsődleges megelőzést célzó, sokféle, több szinten és összehangoltan megvalósított beavatkozások hozhatnak értékelhető eredményt.

A magyar lakosság dohányzása miatt igen jelentős gazdasági hátrányok is kimutathatók: a dohányzásához kapcsolódó közvetlen és közvetett kiadások 2010-ben meghaladták a 440 milliárd forintot (Bakacs és mtsai, 2012). A legfrissebb becslés szerint 2017-re a kiadások mintegy harmadával nőttek, és meghaladták a 652 milliárd forintot (Joó, Bakacs és Vitrai, 2020). A gazdaságot, az ország versenyképességét erősen megterhelő kiadások is alátámasztják, hogy a dohányzás visszaszorítása kiemelt népegészségügyi feladat.

\section{HIVATKOZÁSOK}

Bakacs M., Balku E., Bodrogi J., Demjén T., Joó T., Vámos M., Vitrai J. és Vokó Z. (2012). A dohányzás társadalmi terhei Magyarországon. Kiemelt megállapítások. Budapest, Országos Egészségfejlesztési Intézet. http://www.fokuszpont.dohanyzasvisszaszoritasa.hu/sites/default/files/dohanyzas tarsadalmi terhe OEFI 2012 .pdf

Global Burden of Disease Collaborative Network. (2020) Global Burden of Disease Study 2019 (GBD 2019) Results. Seattle, United States: Institute for Health Metrics and Evaluation (IHME). http://ghdx.healthdata.org/gbd-resultstool

Joó T., Bakacs M. és Vitrai J. (2020) A dohányzás okozta betegségek társadalmi terhei Magyarországon. [Még nem közölt kézirat]. Semmelweis Egyetem Egészségügyi Menedzserképző Központ.

Információk a szerzőről:

Vitrai József, független népegészségügyi szakértő, vitrai.jozsef@gmail.com

\footnotetext{
1 2019-ben Magyarországon a dohányzásnak tulajdonított halálozás becsült értéke 27119 (22 530-32 431) fő volt, ami 100 ezer főre vetítve 328 haláleset jelentett. Az elvesztett egészséges életévek száma 100 ezer főre vetítve 7454 (6287-8854) volt. 1990hez képest a halálozás aránya mintegy 17\%-kal, az elvesztett egészséges életévek aránya 23\%-kal csökkent. A magyar férfiaknál a dohányzásnak tulajdonított halálozás az összes halálozás 27\%-át tette ki, ami mindössze 3\%-kal kisebb, mint 1990-ben volt (GBD, 2019).
} 